\title{
Analisis Pengaruh Layout Penyimpanan Bahan Baku terhadap First In First Out Berdasarkan Hasil Jajak Pendapat Karyawan (Studi pada PT Indofood CBP Sukses Makmur TBK Divisi Packaging Purwakarta)
}

\author{
Fino Wahyudi Abdul ${ }^{\mathrm{a}, 1,{ }^{*} \text {, Muhammad Rizki Ramadhan }}{ }^{\text {b,2 }}$ \\ ${ }^{1,2}$ Institut Ilmu Sosial Dan Manajemen STIAMI, Jakarta, Indonesia \\ ${ }^{1}$ fino@stiami.ac.id*22 R1zk1.ramadhan@yahoo.com
}

ARTICLE INFO

\section{Article history}

Received 2020-10-04

Revised 2020-10-22

Accepted 2020-10-31

Keywords

Penyimpanan, Persepsi, Layout, First In First Out (FIFO)

\begin{abstract}
In a manufacturing company, the role of a warehouse for raw materials (storage) and warehouse for finished products (warehouse) is very important. Because it is impossible for the raw materials that have been ordered directly to be placed on the production floor. So it is with the finished product. It is also impossible for the resulting product to be distributed directly to consumers. This causes the need for a warehouse with a good layout. The aim of this research is to obtain the results of the analysis of the effect of the storage layout of raw materials on firsti in first out (FIFO). The data sources used are primary and secondary company data, as well as data obtained from the company. The theoretical basis used is the theory of influence, layout, and First In First Out. Based on the analysis of employee perception assessment data, it is concluded that the storage layout of raw materials has an effect on the FIFO system
\end{abstract}

\section{A. PENDAHULUAN}

Adanya teknologi saat ini, diharapkan dapat memenuhi kebutuhan manusia. Manusia dapat memanfaatkan teknologi untuk mempermudah perkerjaan mereka, misalkan melakukan manajemen persediaan barang yang terdapat disebuah toko. Persediaan dapat diartikan sebagai barang-barang yang disimpan untuk digunakan atau dijual pada masa atau periode yang akan datang. Persediaan terdiri dari persediaan bahan baku, persediaan bahan setengah jadi dan persediaan barang jadi. Persediaan bahan baku dan bahan setengah jadi disimpan sebelum digunakan atau dimasukkan ke dalam proses produksi, sedangkan persediaan barang jadi atau barang dagangan disimpan sebelum dijual atau dipasarkan. Dengan demikian setiap perusahaan yang melakukan kegiatan usaha umumnya memiliki persediaan. Dalam dunia usaha setiap perusahaan selalu berupaya untuk memperoleh keberhasilan, mendapatkan keuntungan (Profit), dan memperluas jaringan (Network) sehingga setiap perusahaan dapat mengukur sejauh mana perusahaan tersebut dapat bersaing dengan para competitornya untuk menarik minat pembelinya (Larici \& Abdul, 2019).

Dalam dunia manufaktur, tata letak gudang merupakan salah satu hal yang perlu diperhatikan. Dalam perusahaan manufaktur, peran gudang bahan baku (storage) dan gudang produk jadi (warehouse) sangatlah penting. Tidak mungkin bahan baku yang dipesan langsung ditempatkan di lantai produksi. Begitu pula dengan produk jadi. Produk yang dihasilkan juga tidak mungkin langsung didistribusikan kepada konsumen. Hal ini menyebabkan kebutuhan akan adanya gudang dengan tata letak yang baik.

PT. Indofood CBP Sukses Makmur Tbk Divisi Packaging yang terletak di Jalan Kota Bukit Indah Raya Blok.A1 Kav.2-5, Kalihurip, Cikampek, Kalihurip, Kec. Cikampek, Kabupaten Purwakarta, Jawa Barat merupakan perusahaan yang memproduksi berbagai jenis kemasan untuk makanan dan produk konsumen lainnya. Kondisi gudang PT Indofood CBP Sukses Makmur Tbk Divisi Packaging, khususnya gudang penyimpanan banah baku, saat ini kondisi gudang bahan baku belum tertata dengan baik. Hal ini mengakibatkan aliran bahan di gudang tidak first in first out (FIFO) dan kapasitas penyimpanan kurang optimal. Selain itu, penataan yang 
sembarangan di gudang juga mengakibatkan pekerja mengalami kesulitan dalam memasukkan dan mengeluarkan barang yang disimpan. Adapun ruang lingkup penelitian ini yaitu Pengaruh Tata Letak Penyimpanan Bahan Baku Guna Terwujudnya Sistem FIFO DI PT. Indofood CBP Sukses Makmur Tbk Devisi Packaging Purwakarta.

Berdasarkan ruang lingkup yang telah diuraikan diatas maka pertanyaan pada penelitian ini adalah bagaimana pengaruh tata letak penyimpanan bahan baku terhadap FIFO di PT Indofood CBP Sukses Makmur Tbk Divisi Packaging berdasarkan persepsi dari karyawan PT Indofood CBP Sukses Makmur Tbk, Divisi Packaging. Sedangkan tujuan dari penelitian ini juga adalah Menganalisis pengaruh tata letak penyimpanan bahan baku terhadap FIFO di PT Indofood CBP Sukses Makmur Tbk Devisi Packaging berdasarkan persepsi karyawan PT Indofood CBP Sukses Makmur Tbk Divisi Packaging.

Dalam beberapa penelitian terdahulu. Pertama, penelitian yang dilakukan oleh (Noerfajr \& Suliantoro, 2016), yang memiliki tujuan untuk mengatasi permasalahan sistem penataan yang ada di warehouse PT. Sandang Asia Maju Abadi dan agar dapat menerapkan metode FIFO, dengan hasil diterapkannya Standart Operating Procedure (SOP) penataan dengan menggunakan metode FIFO untuk memudahkan pendataan sehingga dapat mengurangi waste dan kerugian di perusahaan. Diterapkannya SOP Penamaan yang terstandar menggunakan Kartu Nama Barang dan Information Card untuk memudahkan sistem pendataan terpadu sehingga dapat dikembangkan sistem pendataan berbasis teknologi yang lebih canggih dikemudian hari. Diterapkannya alur keluar masuk barang di warehouse PT. Sandang Asia Maju Abadi untuk memudahkan material handling serta mengurangi waste yang disebabkan oleh kurang teraturnya aliran keluar masuk barang. Dilakukan monitoring dan evaluasi secara berkala terhadap sistem penataan di warehouse yang melibatkan seluruh komponen yang ada dan bertugas di warehouse, Kedua, Penelitian yang dilakukan oleh Nasiruddin dan Syaifulloh (2019), dengan tujuan penelitian ini adalah untuk menjamin agar pengelolaan persediaan sesuai dengan kebijakan manajemen BUMP, maka dibutuhkan suatu sistem yang mampu menjamin tercapainya tujuan bisnis, salah satunya dengan menerapkan metode FIFO. Metode penelitian yang digunakan adalah penelitian pendekatan kuantitatif dengan hasil Persamaan regresi berganda $\hat{Y}=0,31.767+0,723 X+1,025$. Hal ini menunjukan bahwa setiap kenaikan satu satuan variabel harga pokok penjualan sebesar 0,723 dan variabel laba bersih sebesar 1,025 dapat meningkatkan pencatatan sistem periodik dengan FIFO pada satuan konstanta sebesar 31,371. Dari kedua penelitian tersebut dapat disimpulkan bahwa optimalisi dalam tata letak penyimpanan bahan baku dapat berpengaruh terhadap berjalannya sistem first in first out (FIFO dalam sebuah perusahaan.

Menurut Hugiono dan Poerwantana (2000:47) pengaruh merupakan dorongan atau bujukan dan bersifat membentuk atau merupakan suatu efek, sedangkan menurut Badudu dan Zain (2001) pengaruh adalah daya yang menyebabkan sesuatu terjadi, sesuatu yang dapat membentuk atau mengubah sesuatu yang lain dan tunduk atau mengikuti karena kuasa atau kekuasaan orang lain. Berdasarkan konsep pengaruh tersebut dapat disimpulkan bahwa pengaruh merupakan suatu dampak yang timbul atau dihasilkan dari suatu kejadian atau fenomena yang saling berhubungan.

Tujuan tata letak adalah untuk mendapatkan susunan tata letak yang paling baik dari fasilitas-fasilitas produksi yang terdapat di ruang produksi dan pergudangan. Sehingga dengan adanya susunan tata letak yang baik, diharapkan pelaksanaan proses produksi dan sistem-sistem yang ada di dalamnya, akan dapat berjalan dengan lancar dan para karyawan akan dapat menyelesaikan tugas yang diberikan kepada mereka dengan optimal (Reid \& Sanders, 2013; Russell \& Taylor, 2016).

Menurut Tompkins, dkk. (2010), metode FIFO (first in first out) menganggap bahwa harga pokok dari barang-barang yang pertama kali dibeli akan merupakan barang yang dijual pertama kali. Dalam metode ini persediaan akhir dinilai dengan harga pokok pembelian yang paling akhir. Metode ini juga mengasumsikan bahwa barang yang terjual karena pesanan adalah barang yang mereka beli. Oleh karenanya, barang-barang yang dibeli pertama kali adalah barang-barang pertama yang dijual dan barang-barang sisa di tangan (persediaan akhir) diasumsikan untuk biaya akhir. Karenanya, untuk penentuan pendapatan, biaya-biaya sebelumnya dicocokkan dengan pendapatan 
dan biaya-biaya yang baru digunakan untuk penilaian laporan neraca. Metode ini konsisten dengan arus biaya aktual, sejak pemilik barang dagang mencoba untuk menjual persediaan lama pertama kali. FIFO merupakan yang paling luas digunakan dalam penilaian persediaan.

Melihat berbagai macam keuntungan dari sistem FIFO ini tidak terlepas pula dari kelemahankelemahan yang terdapat pada sistem ini. Biasanya sistem ini kurang efektif apabila pihak-pihak pergudangan tidan mampu menata letak barang-barang secara berurutan sesuai tanggal atau waktu barang karena barang yang diterima merupakan barang lama yang dianggap barang tersebut kualitasnya kurang baik.

\section{B. METODE}

Penelitian ini merupakan penelitian deskriptif kuantitatif dengan pendekatan survei, yaitu penelitian dengan menganalisa angka-angka yang diperoleh dari hasil survei dalam bentuk penyebaran kuesioner kepada sample penelitian. Metode yang digunakan dalam penelitian ini adalah deskriptif dan verifikatif, dengan pendekatan kuantitatif. Metode deskriptif merupakan metode yang berfungsi untuk menganalisis suatu data dengan cara mendeskripsikan atau menggambarkan data yang terkumpul agar dapat membuat kesimpulan yang berlaku umum atau generalisasi (Sugiono, 2016). pengumpulan data menggunakan instrumen penelitian, analisis data ini bersifat kuantitatif statistik yang bertujuan untuk menguji hipotesis yang sudah dibuat

Operasionalisasi variabel diperlukan untuk menentukan dimensi, indikator, serta skala dari variabel-variabel yang terkait dalam penelitian. Sesuai dengan judul penelitian yaitu Pengaruh Tata Letak Penyimpanan Bahan Baku Terhadap FIFO, maka terdapat 2 variabel penelitian yaitu tata letak penyimpanan (X) dan FIFO (Y). Variabel X (tata letak penyimpanan bahan baku) dan variabel Y (FIFO) dalam penelitian ini menggunakan metode deskriptif agar mengetahui gambaran variabel tersebut secara sistematis, sedangkan metode verifikatif digunakan untuk mengukur fenomenafenomena yang ada dalam penelitian dengan menggunakan alat bantu statistik.

Data penelitian yang digunakan adalah primer dan sekunder. Pengumpulan data dalam penelitian ini adalah dengan menggunakan kuesioner dan skala penilaiannya menggunakan skala linkert yaitu 1 = sangat tidak baik (STB), 2 = tidak baik (TB), $3=$ cukup baik (CB), 4 = baik (B), dan $5=$ sangat baik (SB). Survei yang dilakukan dengan menggunakan teknik sampling, untuk mendapatkan gambaran tentang pandangan-pandangan dari pelanggan, dengan mengajukan serangkaian pertanyaan kepada beberapa orang yang dianggap mewakili populasi pelanggan dan kemudian menyimpulkan jawaban-jawabannya sebagai gambaran dari populasi yang lebih luas.

\section{HASIL DAN PEMBAHASAN}

Deskripsi profil responden adalah menguraikan dan memberikan gambaran mengeai identitas responden dalam penelitian ini. Adapun profil responden dalam penelitian ini meliputi jenis kelamin, Jenis Kelamin, Kategori Pelanggan, dan Lama Berlangganan yang dapat di gambarkan pada tabel karateristik responden berdasrkan usia, jenis kelamin, jenjang pendidikan dan masa kerja. Data yang telah dikumpulkan pada penelitian ini adalah 60 responden.

\section{Profil responden berdasarkan jenis kelamin}

Berdasarkan kuisioner yang dibagikan kepada 60 responden diperoleh data tentang jenis kelamin reaponden. Adapun secara lengkap deskripsi responden berdasarkan jenis kelamin yang ditunjukkan oleh Tabel 1 berikut:

Tabel 1. Karakteristik responden berdasarkan jenis kelamin

\begin{tabular}{rlcc}
\hline NO & JENIS KELAMIN & JUMLAH (Org) & PERSENTASE (\%) \\
\hline 1 & Pria & 60 & $100.00 \%$ \\
\hline 2 & Wanita & 0 & $0.00 \%$ \\
\hline & JUMLAH & $\mathbf{6 0}$ & $\mathbf{1 0 0 \%}$ \\
\hline
\end{tabular}

Sumber : Hasil Olah Data Jawaban Responden, tahun 2020 
Dari Tabel 1 diatas dapat diketahui bahwa dari 60 responden terdapat 60 responden atau $100,00 \%$ adalah pria dan 0 responden atau $0,00 \%$ adalah wanita. Berdasarkan data tersebut menunjukkan bahwa mayoritas responden adalah pria dengan jumlah 60 responden atau 100,00\%. Di PT Indofood CBP Sukses Makmur Tbk Divisi Packaging Purwakarta 90\% adalah pria sedangkan $10 \%$ wanita yang tidak ada kaitannya dengan penelitian.

\section{Profil responden berdasarkan usia}

Berdasarkan kuisioner yang dibagikan kepada 60 responden diperoleh data tentang usia responden kerja karyawan PT Indofood CBP Sukses Makmur Tbk Divisi Packaging Purwakarta. Adapun secara lengkap deskripsi responden berdasarkan usia responden ditunjukkan pada Tabel 2 berikut ini :

Tabel 2. Karakteristik responden berdasarkan usia

\begin{tabular}{cccc}
\hline & & JUMLAH (Org) & PERSENTASE (\%) \\
\hline NO & USIA & & \\
\hline 1 & $20-30$ & 35 & $58.30 \%$ \\
\hline 2 & $31-40$ & 20 & $33.30 \%$ \\
\hline 3 & $41-55$ & 5 & $8.40 \%$ \\
\hline & JUMLAH & $\mathbf{6 0}$ & $\mathbf{1 0 0 \%}$ \\
\hline
\end{tabular}

Sumber : Hasil Olah Data Jawaban Responden, 2020

Dari Tabel 2 diatas terlihat dari 60 responden, terdapat 35 responden atau 58,30\% berumur antara 20 - 30 tahun, 20 responden atau 33,30\% berumur antara $31-40$ tahun dan 5 responden atau $8,40 \%$ yang berusia $41-55$ tahun. Berdasarkan data tersebut menunjukkan bahwa mayoritas usia responden antara 20 - 30 tahun dengan jumlah 35 orang.

\section{Karakteristik responden berdasarkan jenjang pendidikan}

Berdasarkan kuisioner yang dibagikan kepada 60 responden diperoleh data tentang jenjang pendidikan responden. Adapun secara lengkap deskripsi profil responden berdasarkan jenjang pendidikan diperlihatkan pada Tabel 3 berikut ini :

Tabel 3. Profil responden berdasarkan jenjang pendidikan

\begin{tabular}{llll}
\hline NO & TINGKAT & JUMLAH (Org) & \\
\hline 1 & PENDIDIKAN & & PERSENTASE \\
\hline 2 & SD & 0 & $0.00 \%$ \\
\hline 3 & SMA & 2 & $3.30 \%$ \\
\hline 4 & SARJANA & 56 & $83.40 \%$ \\
\hline JUMLAH & & 2 & $3.30 \%$ \\
\hline
\end{tabular}

Sumber : Hasil Olah Data Jawaban Responden, 2020

Dari Tabel 3 diatas diketahui bahwa dari 60 responden karyawan yang PT Indofood CBP Sukses makmur Tbk Divisi Packaging Purwakarta terdapat 2 responden atau 3,30\% memiliki tingkat pendidikan SMP, 56 responden atau 83,40\% memiliki tingkat pendidikan SMA dan 2 responden atau 3,30\% memiliki tingkat pendidikan Sarjana. Berdasarkan data di atas maka mayoritas tingkat pendidikan responden adalah SMA dengan jumlah 56 oran

\section{Karakteristik responden berdasarkan masa kerja}

Berdasarkan kuisioner yang dibagikan kepada 60 responden diperoleh data tentang masa kerja responden. Adapun secara lengkap deskripsi responden berdasarkan masa kerja diperlihatkan pada Tabel 4 berikut ini : 
Tabel 4. Karakteristik responden berdasarkan masa kerja

\begin{tabular}{ccccc}
\hline \multirow{2}{*}{ NO } & \multicolumn{2}{c}{ MASA KERJA } & JUMLAH (Org) & PERSENTASE \\
\hline 1 & $1-5$ & Tahun & 5 & $8.30 \%$ \\
\hline 2 & $6-10$ Tahun & 30 & $50.00 \%$ \\
\hline 3 & $11-15$ Tahun & 20 & $33.40 \%$ \\
\hline 4 & $16-20$ Tshun & 5 & $8.300 \%$ \\
\hline & JUMLAH & $\mathbf{6 0}$ & $\mathbf{1 0 0 \%}$ \\
\hline
\end{tabular}

Sumber : Hasil Olah Data Jawaban Responden, 2020

Dari Tabel 4 diatas Berdasarkan data diketahui bahwa dari 60 responden karyawan yang PT Indofood CBP Sukses Makmur Tbk Divisi Packaging Purwakarta terdapat 5 responden atau $8,30 \%$ memiliki masa kerja 1 - 5 Tahun, 30 responden atau 50,00\% memiliki masa kerja 6 - 10 Tahun, 20 responden atau 33,40\% memiliki masa kerja 11 - 15 Tahun dan 5 responden atau 8,30\% memiliki masa kerja 16 - 20 Tahun. Berdasarkan data di atas maka mayoritas masa kerja responden adalah 6 - 10 Tahun dengan jumlah 30 responden atau $50,00 \%$.

\section{Uji validitas}

Pengujian validitas data dalam penelitian ini dilakukan secara statistik untuk menghitung korelasi antara masing-masing pertanyaan dengan skor total dengan menggunakan Product Moment Pearson Correlation.

Tabel 5. Hasil uji validitas variable tata letak

\begin{tabular}{llc}
\hline \multicolumn{1}{c}{ BUTIR INSTRUMENT } & $\begin{array}{c}\text { KOEFESIEN } \\
\text { KORELASI }\end{array}$ & KET. \\
\hline Susunan Bahan Baku sudah sesuai dengan standar & $0,836>0,3$ & Valid \\
\hline $\begin{array}{l}\text { Susunan Bahan Baku memudahkan petugas gudang dalam } \\
\text { pengambilan bahan baku }\end{array}$ & $0,858>0,3$ & Valid \\
\hline $\begin{array}{l}\text { Jumlah Bahan Baku dalam satu palet sudah sesuai standar } \\
\text { sehingga memudahkan dalam penyusunan } \\
\text { Bahan Baku }\end{array}$ & $0,824>0,3$ & Valid \\
\hline $\begin{array}{l}\text { Tinggi Bahan Baku dalam satu palet sudah memenuhi } \\
\text { standar penyusunan bahan baku }\end{array}$ & $0,846>0,3$ & Valid \\
\hline $\begin{array}{l}\text { Penumpukan Bahan Baku sudah sesuai standar } \\
\text { Gang di setiap barisan Bahan Baku memudahkan } \\
\text { petugas gudang dalam pengecekan }\end{array}$ & $0,804>0,3$ & Valid \\
\hline $\begin{array}{l}\text { Jarak Bahan Baku satu dengan yang lain } \\
\text { mempermudah petugas gudang dalam pengecekan dan } \\
\text { pengambilan Bahan baku }\end{array}$ & $0,641>0,3$ & Valid \\
\hline $\begin{array}{l}\text { Jenis Bahan Baku dikelompokan agar berada di satu titik untuk } \\
\text { satu jenis }\end{array}$ & $0,755>0,3$ & Valid \\
\hline $\begin{array}{l}\text { Ukuran Bahan Baku di sesuaikan guna mempermudah petugas } \\
\text { gudang }\end{array}$ & $0,707>0,3$ & Valid \\
\hline $\begin{array}{l}\text { Setiap Bahan Baku di sesuaikan peruntukan serta } \\
\text { penggunaanya agar mempermudah dalam proses pengambilan } \\
\text { bahan baku }\end{array}$ & $0,699>0,3$ & Valid \\
\hline $\begin{array}{l}\text { Sumbe : Data } \\
\text { and }\end{array}$ & & \\
\hline
\end{tabular}

Sumber : Data Hasil Pengolahan SPSS Dari Jawaban Kuesioiner,2020

Dari hasil rekapitulasi Tabel 5 diatas, diperoleh bahwa pada variabel Tata Letak semua indikator yang tertuang dalam sebuah pernyataan pada kuesioner dinyatakan valid karena 
nilai koefesien Korelasinya $>0,3$, hal ini dapat diartikan bahwa hasil pada Tabel 5 adalah valid.

Tabel 6. Uji validitas variable Firs In First Out (FIFO)

\begin{tabular}{|c|c|c|}
\hline BUTIR INSTRUMENT & $\begin{array}{l}\text { KOEFESIEN } \\
\text { KORELASI }\end{array}$ & KET. \\
\hline Susunan Bahan Baku sudah sesuai dengan standar & $0,836>0,3$ & Valid \\
\hline $\begin{array}{l}\text { Susunan Bahan Baku memudahkan petugas gudang dalam } \\
\text { pengambilan bahan baku }\end{array}$ & $0,858>0,3$ & Valid \\
\hline $\begin{array}{l}\text { Jumlah Bahan Baku dalam satu palet sudah sesuai standar } \\
\text { sehingga memudahkan dalam penyusunan } \\
\text { Bahan Baku }\end{array}$ & $0,824>0,3$ & Valid \\
\hline $\begin{array}{l}\text { Tinggi Bahan Baku dalam satu palet sudah memenuhi } \\
\text { standar penyusunan bahan baku }\end{array}$ & $0,846>0,3$ & Valid \\
\hline Penumpukan Bahan Baku sudah sesuai standar & $0,804>0,3$ & Valid \\
\hline Gang di setiap barisan Bahan Baku memudahkan & $0,766>0,3$ & Valid \\
\hline \multicolumn{3}{|l|}{ petugas gudang dalam pengecekan } \\
\hline $\begin{array}{l}\text { Jarak Bahan Baku satu dengan yang lain } \\
\text { mempermudah petugas gudang dalam pengecekan dan } \\
\text { pengambilan Bahan baku }\end{array}$ & $0,641>0,3$ & Valid \\
\hline $\begin{array}{l}\text { Jenis Bahan Baku dikelompokan agar berada di satu titik untuk } \\
\text { satu jenis }\end{array}$ & $0,755>0,3$ & Valid \\
\hline $\begin{array}{l}\text { Ukuran Bahan Baku di sesuaikan guna mempermudah petugas } \\
\text { gudang }\end{array}$ & $0,707>0,3$ & Valid \\
\hline $\begin{array}{l}\text { Setiap Bahan Baku di sesuaikan peruntukan serta } \\
\text { penggunaanya agar mempermudah dalam proses } \\
\text { pengambilan bahan baku }\end{array}$ & $0,699>0,3$ & Valid \\
\hline
\end{tabular}

Sumber : Data Hasil Pengolahan SPSS Dari Jawaban Kuesioiner tahun 2020

Dari hasil pengujian data dengan menggunakan program SPSS pada variabel first in first out semua indikator yang tertuang dalam sebuah pernyataan pada kuesioner dinyatakan valid karena nilai koefesien Korelasinya $>0,3$, hal ini dapat diartikan bahwa hasil pada Tabel 6 adalah valid.

\section{Uji reliabilitas variabel}

Suatu instrumen dikatakan reliabel jika nilai cronbach alpha lebih besar dari 0,6. Setelah menilai alpha, selanjutnya membandingkan nilai tersebut dengan angka kritis reliabilitas. Instrumen yang dipakai dalam variabel diketahui handal (reliabel) apabila memiliki cronbach alpha $>0,60$.

Tabel 7. Uji reliabilitas

\begin{tabular}{clcc}
\hline NO & VARIABEL & $\begin{array}{c}\text { CRONBACH } \\
\text { ALPHA }\end{array}$ & KETERANGAN \\
\hline 1 & Tata Letak $(\mathrm{X})$ & 0.920 & Reliabel Nilai \\
\hline 2 & First In First Out $(\mathrm{Y})$ & 0.896 & Alpha $>0,6$ \\
\hline
\end{tabular}

Sumber : Data Hasil Pengolahan SPSS Dari Jawaban Kuesioiner,2020

Berdasarkan Tabel 7 dapat disimpulkan bahwa semua variabel yang digunakan dalam penelitian ini adalah reliabel, karena memiliki nilai Cronbach Alpha $(\alpha)$ lebih besar dari 0,60. Sesuai yang disyaratkan oleh Ghozali (2005:42) bahwa suatu konstruk dikatakan reliabel jika nilai Cronbach Alpha> 0,60. 


\section{Uji normalitas}

Uji normalitas digunakan untuk menguji apakah sampel yang digunakan mempunyai distribusi normal atau tidak.Dalam model regresi linier, asumsi ini ditunjukkan oleh nilai error (å) yang berdistribusi normal.Model regresi yang baik adalah model regresi yang memiliki distribusi normal atau mendekati normal, sehingga layak dilakukan pengujian secara statistik. Pengujian normalitas data menggunakan Test of Normality Kolmogorov-Smirnov.

Tabel 8. Uji normalitas

\begin{tabular}{|c|c|c|}
\hline \multicolumn{3}{|c|}{ One-Sample Kolmogorov-Smirnov Test } \\
\hline \multicolumn{3}{|c|}{ Unstandardized Residual } \\
\hline $\mathrm{N}$ & & 60 \\
\hline \multirow[b]{2}{*}{ Parameters $^{\mathfrak{a}, \mathrm{U}}$} & Mean & 0 \\
\hline & $\begin{array}{l}\text { Std. } \\
\text { Deviation }\end{array}$ & 4,06236588 \\
\hline \multirow{3}{*}{$\begin{array}{l}\text { Most Extreme } \\
\text { Differences }\end{array}$} & Absolute & 0,092 \\
\hline & Positive & 0,067 \\
\hline & Negative & $-0,092$ \\
\hline \multicolumn{2}{|l|}{ Test Statistic } & 0,092 \\
\hline \multirow{2}{*}{\multicolumn{2}{|c|}{$\begin{array}{l}\text { Asymp. Sig. (2-tailed) } \\
\text { a. Test distribution is Normal. }\end{array}$}} & $.200^{\mathrm{c}, \mathrm{d}}$ \\
\hline & & \\
\hline \multicolumn{3}{|c|}{ b. Calculated from data. } \\
\hline \multicolumn{3}{|c|}{ c. Lilliefors Significance Correction. } \\
\hline
\end{tabular}

Sumber : Data hasil pengolahan SPSS dari jawaban kuesioiner, tahun 2020

Hasil penghitungan Tabel 8 di atas menunjukkan, bahwa semua indikator pada variabel kinerja berdistribusi normal, karena nilai Kolmogorov-Smirnov $=0,200>0,05$.

8. Analisis deskriptif variable tata letak

Data dari hasil penelitian untuk variabel bebas pertama yaitu variabel Tata Letak (X) yang dijaring melalui penyebaran kuesioner dengan jumlah pertanyaan sebanyak 10 butir instrument dengan penggunaan skala pilihan jawaban mulai dari skala 1 hingga skala 5 ( 5 opsion), berikut Tabel 9 dan Tabel 10 adalah hasil jawabannya

Tabel 9. Analisis deskriptif variable tata letak

\begin{tabular}{|c|c|c|c|c|c|c|c|c|c|c|c|c|c|}
\hline \multirow{2}{*}{ No. } & \multirow{2}{*}{ Indikator } & \multicolumn{10}{|c|}{ Frekuensi Masing-masing Jawaban } & \multicolumn{2}{|c|}{$\begin{array}{c}\text { Total } \\
\text { Frekuensi }\end{array}$} \\
\hline & & $\mathbf{1}$ & $\%$ & 2 & $\%$ & 3 & $\%$ & 4 & $\%$ & 5 & $\%$ & Frek & $\%$ \\
\hline 1 & $\begin{array}{l}\text { Susunan Bahan Baku sudah sesuai } \\
\text { dengan standar }\end{array}$ & 1 & 1.66 & 2 & 3.34 & 3 & 5.00 & 33 & 55.00 & 21 & 35.00 & 60 & 100 \\
\hline 2 & $\begin{array}{lcr}\text { Susunan } & \text { Bahan } & \text { Baku } \\
\text { memudahkan petugas gudang } & \text { guan } \\
\text { dalam pengambilan bahan baku }\end{array}$ & 1 & 1.66 & 4 & 6.66 & 7 & 11.69 & 31 & 51.66 & 17 & 28.33 & 60 & 100 \\
\hline 3 & $\begin{array}{llr}\text { Jumlah } & \text { Bahan Baku dalam satu } \\
\text { palet sudah sesuai } & \text { standar } \\
\text { sehingga memudahkan } & \text { dalam } \\
\text { penyusunan Bahan Baku } & \\
\end{array}$ & 0 & 0.00 & 0 & 0.00 & 6 & 10.00 & 33 & 55.00 & 21 & 35.00 & 60 & 100 \\
\hline 4 & $\begin{array}{l}\text { Tinggi Bahan Baku dalam satu } \\
\text { palet sudah memenuhi standar }\end{array}$ & 0 & 0.00 & 5 & 8.33 & 6 & 10.00 & 33 & 55.00 & 16 & 26.67 & 60 & 100 \\
\hline
\end{tabular}


penyusunan bahan baku

5 Penumpukan Bahan Baku sudah sesuai standar

6 Gang di setiap barisan Bahan Baku

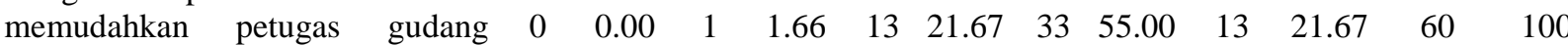
dalam pengecekan

7 Jarak Bahan Baku satu dengan yang lain mempermudah petugas gudang dalam pengecekan dan pengambilan Bahan baku

8 Jenis Bahan Baku dikelompokan agar berada di satu titik untuk satu $\quad \begin{array}{llllllllllll}0 & 0.00 & 7 & 11.69 & 15 & 25.00 & 28 & 46.65 & 10 & 16.66 & 60 & 100\end{array}$ jenis

9 Ukuran Bahan Baku di sesuaikan

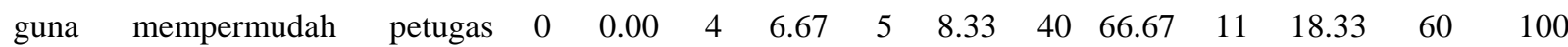
gudang

10 Setiap Bahan Baku di sesuaikan peruntukan serta penggunaanya agar mempermudah dalam proses pengambilan bahan baku

\begin{tabular}{|c|c|c|c|c|c|c|c|c|c|c|c|}
\hline 0 & 0.00 & 0 & 0.00 & 8 & 13.33 & 35 & 58.34 & 17 & 28.33 & 60 & 100 \\
\hline 0 & 0.00 & 1 & 1.66 & 13 & 21.67 & 33 & 55.00 & 13 & 21.67 & 60 & 100 \\
\hline 0 & 0.00 & 11 & 18.33 & 4 & 6,67 & 33 & 55.00 & 12 & 20.00 & 60 & 100 \\
\hline 0 & 0.00 & 7 & 11.69 & 15 & 25.00 & 28 & 46.65 & 10 & 16.66 & 60 & 100 \\
\hline 0 & 0.00 & 4 & 6.67 & 5 & 8.33 & 40 & 66.67 & 11 & 18.33 & 60 & 100 \\
\hline 0 & 0.00 & 0 & 0.00 & 8 & 13.33 & 41 & 68.34 & 11 & 18.33 & 60 & 100 \\
\hline
\end{tabular}
Sumber : Data Hasil Pengolahan SPSS Dari Jawaban Kuesioiner,2020

Tabel 10. rekapitulasi distribusi frekuensi jawaban responden terhadap variabel tata letak

\begin{tabular}{|c|c|c|c|}
\hline No & Indikator / pernyataan & Jumlah skor & Keterangan \\
\hline 1 & Susunan Bahan Baku sudah sesuai dengan standar & 251 & Cukup \\
\hline 2 & $\begin{array}{l}\text { Susunan Bahan Baku memudahkan petugas gudang dalam } \\
\text { pengambilan bahan baku }\end{array}$ & 239 & Cukup \\
\hline 3 & $\begin{array}{l}\text { Jumlah Bahan Baku dalam satu palet sudah sesuai } \\
\text { standar sehingga memudahkan dalam penyusunan } \\
\text { Bahan Baku }\end{array}$ & 255 & Cukup \\
\hline 4 & $\begin{array}{l}\text { Tinggi Bahan Baku dalam satu palet sudah memenuhi } \\
\text { standar penyusunan bahan baku }\end{array}$ & 240 & Cukup \\
\hline 5 & Penumpukan Bahan Baku sudah sesuai standar & 249 & Cukup \\
\hline 6 & $\begin{array}{l}\text { Gang di setiap barisan Bahan Baku memudahkan } \\
\text { petugas gudang dalam pengecekan }\end{array}$ & 238 & Cukup \\
\hline 7 & $\begin{array}{l}\text { Jarak Bahan Baku satu dengan yang lain } \\
\text { mempermudah petugas gudang dalam pengecekan } \\
\text { dan pengambilan Bahan baku }\end{array}$ & 226 & Cukup \\
\hline 8 & $\begin{array}{l}\text { Jenis Bahan Baku dikelompokan agar berada di satu titik } \\
\text { untuk satu jenis }\end{array}$ & 221 & Cukup \\
\hline 9 & $\begin{array}{l}\text { Ukuran Bahan Baku di sesuaikan guna mempermudah } \\
\text { petugas gudang }\end{array}$ & 238 & Cukup \\
\hline 10 & $\begin{array}{l}\text { Setiap Bahan Baku di sesuaikan peruntukan serta } \\
\text { penggunaanya agar mempermudah dalam proses } \\
\text { pengambilan bahan baku }\end{array}$ & 243 & Cukup \\
\hline & Jumlah & 2.400 & \\
\hline & Rata-rata & 240 & Cukup \\
\hline
\end{tabular}

Sumber : Hasil Jawaban Responden, 2020

Total keseluruhan dari kuesioner tentang kepemimpinan yang dibagikan kepada 60 responden menghasilkan angka sebesar 2.400 dengan rata-rata sebesar 240. Angka tersebut berada pada interval pernyataan Cukup Baik. Hal ini berarti bahwa Tata Letak Penyimpanan yang dilakukan cukup berpengaruh terhadap Sistem first in first out (FIFO). Hal itu terlihat dari jawaban responden yang berada pada skala interval Cukup Baik. 


\section{Analisis deskriptif variable first in first out (FIFO)}

Data dari hasil penelitian untuk variabel first in first out (Y) yang dijaring melalui penyebaran kuesioner dengan jumlah pertanyaan sebanyak 12 butir instrument dengan penggunaan skala pilihan jawaban mulai dari skal 1 hingga skala 5 (5 opsion), adalah diperlihatkan pada Tabel 9 dan 10, berikut adalah hasil jawabannya

Tabel 11. Rekapitulasi distribusi frekuensi jawaban responden terhadap variabel First In First Out

\begin{tabular}{clcc}
\hline No & \multicolumn{1}{c}{ Indikator / pernyataan } & Jumlah skor & Keterangan \\
\hline & $\begin{array}{l}\text { Saya melakukan pencarian barang sesuai } \\
\text { permintaan produksi }\end{array}$ & 258 & Cukup Baik \\
\hline 2 & Saya mencari barang yang mudah ditemukan & 257 & Cukup baik \\
\hline 3 & Saya melakukan pencarian barang berdasarkan list & 226 & Cukup baik \\
\hline 4 & $\begin{array}{l}\text { Saya mengutamakan mencari barang paling } \\
\text { depan sesuai yang saya butuhkan }\end{array}$ & 223 & Cukup Baik \\
\hline 5 & $\begin{array}{l}\text { Saya melakukan pengambilan barang sesuai } \\
\text { kebutuhan produksi }\end{array}$ & 248 & Cukup Baik \\
\hline 5 & $\begin{array}{l}\text { Saya melakukan pengambilan barang sesuai } \\
\text { kebutuhan produksi }\end{array}$ & 248 & Cukup Baik \\
\hline 7 & Saya mudah menemukan barang & 224 & Cukup Baik \\
\hline $\begin{array}{l}\text { Saya melakukan pengambilan barang melihat tanggal } \\
\text { kedatangan }\end{array}$ & $\begin{array}{l}\text { Saya melakukan pengambilan barang yang } \\
\text { mudah di jangkau }\end{array}$ & Cukup baik \\
\hline 9 & $\begin{array}{l}\text { Saya mengutamakan pengambilan barang paling } \\
\text { depan }\end{array}$ & 222 & Cukup Baik \\
\hline & $\begin{array}{l}\text { Saya melakukan pengambilan barang } \\
\text { berdasarkan label kedatangan paling lama }\end{array}$ & 230 & Cukup Baik \\
\hline
\end{tabular}

Sumber : Hasil Jawaban Responden, tahun 2020

Berdasarkan Tabel 9 dan 10, dari total keseluruhan dari kuesioner yang dibagikan kepada 60 responden menghasilkan angka sebesar 2.329 dengan rata-rata sebesar 232,9. Angka tersebut berada pada interval pernyataan Cukup Baik. Hal ini berarti bahwa sistem first in first out yan di jalani perusahaan Cukup Baik Berpengaruh terhadap ketidak tepatan Tata Letak penyimpanan. Hal itu terlihat dari jawaban responden yang berada pada skala interval Cukup Baik.

\section{Uji korelasi antar variabel}

Analisis korelasi digunakan untuk mengetahui besaran koefisien di antara variabel Tata Letak terhadap first in first out (FIFO).

Tabel 11. Hasil Uji korelasi tata letak terhadap FIFO

\begin{tabular}{|c|c|c|c|}
\hline \multicolumn{4}{|c|}{ Correlations } \\
\hline & & Tata Letak & First In First Out \\
\hline \multirow{3}{*}{ Tata Letak } & Pearson Correlation & 1 &, $583^{* *}$ \\
\hline & Sig. (2-tailed) & & 0 \\
\hline & $\mathrm{N}$ & 60 & 60 \\
\hline \multirow{3}{*}{ First In First Out } & Pearson Correlation &, $583^{* * *}$ & 1 \\
\hline & Sig. (2-tailed) & 0 & \\
\hline & $\mathrm{N}$ & 60 & 60 \\
\hline
\end{tabular}

Sumber : Data pengolahan SPSS Dari jawaban koesioner tahun 2020

Dari hasil analisis pada Tabel 11, diperoleh besaran koefisien korelasi diantara variabel

Tata Letak dengan first in furst out (FIFO) sebesar 0,583. Dengan demikian korelasi tata letak 
dengan first in first out memiliki tingkat korelasi Sedang dan nilainya positif dikarenakan berada di interval koefisien nilai 0,40 - 0,599. (Sugiyono, 2016).

Berdasarkan hasil pengolahan data dengan bantuan software SPSS. Didapatkan koefisien jalur untuk setiap variabel tata letak penyimpana terhadap sistem first in first out. Hasil analisis tersebut dapat dilihat pada Tabel 12, berikut ini

Tabel 12. Nilai coefficients variabel tata letak terhadap FIFO

\begin{tabular}{|c|c|c|c|c|c|c|c|}
\hline \multicolumn{8}{|c|}{ Coefficients $^{\mathrm{a}}$} \\
\hline \multirow[b]{2}{*}{ Model } & $\begin{array}{r}\text { Unstan } \\
\text { Coeff } \\
\end{array}$ & dized & $\begin{array}{c}\text { Standardized } \\
\text { Coefficients }\end{array}$ & \multirow[b]{2}{*}{$\mathrm{T}$} & \multirow[b]{2}{*}{ Sig. } & \multicolumn{2}{|c|}{ Collinearity Statistics } \\
\hline & B & $\begin{array}{l}\text { Std. } \\
\text { Error }\end{array}$ & Beta & & & Tolerance & VIF \\
\hline 1 (Constant) & 18,769 & 3,617 & & 5,189 & 0,000 & & \\
\hline Tata Letak & 0,503 & 0,089 & 0,594 & 5,622 & 0,000 & 1,000 & 1,000 \\
\hline
\end{tabular}

a. Dependent Variable: First In First Out

Sumber : Data pengolahan SPSS Dari jawaban koesioner tahun 2020

Berdasarkan hasil pengolahan data pada Tabel 12 dimana data tersebut diperoleh dari pengolahan data hasil kuesioner dengan bantuan software SPSS. Dari hasil tersebut didapatkan koefisien jalur untuk setiap variabel sebagai berikut : 1). Pengaruh parsial variabel Tata Letak (X) Terhadap sistem FIFO (Y) adalah Y = 0,594 X, dengan nilai koefisien standar 0,594 dan persamaan jalurnya

$$
Y=(0,594 X)+\varepsilon
$$

Dimana $: \mathrm{X}=$ tata letak; $\mathrm{Y}=\mathrm{FIFO}$

Pengaruh simultan X terhadap Y. Berdasarkan Tabel 13., menunjukan bahwa total pengaruh variabel tata letak terhadap first in first out sebesar 0,1188 atau $11,88 \%$. Artinya bahwa berjalannya sistem first in first out dipengaruhi oleh variabel tata letak penyimpanan bahan baku sebesar 11,88\%. Sedangkan sisanya dipengaruhi oleh variabel lain sebesar $88,12 \%(=1-$ 0,1188 ) yang tidak diteliti $(\varepsilon)$.

Tabel 13. Pengaruh simultan X terhadap Y

\begin{tabular}{ccccc}
\hline \multirow{2}{*}{ Var. Koefisien Jalur } & $\begin{array}{c}\text { Pengaruh } \\
\text { Langsung }\end{array}$ & $\begin{array}{c}\text { Pengaruh Tidak } \\
\text { Langsung }\end{array}$ & $\begin{array}{l}\text { Sub Total } \\
\text { Pengaruh }\end{array}$ \\
\cline { 3 - 4 } & 0,594 & 0,1188 & $\mathrm{X}$ & 0,1188 \\
\hline $\mathrm{X}$ & & --- & 0,1188 \\
\hline Total Pengaruh & & & \\
\hline
\end{tabular}

Sumber : Data hasil pengolahan data, tahun 2020

\section{Analisis regresi linier sederhana}

Pengujian regresi linier sederhana untuk menunjukan kebenaran pengaruh yang signifikan antara tata letak terhadap first in first out, dalam penelitian ini menggunakan hasil penghitungan SPSS. Maka didapatkan koefisien regresi sederhana yang diperlihatkan pada Tabel 14.

Tabel 14. Regresi sederhana

\begin{tabular}{|c|c|c|c|c|c|}
\hline \multicolumn{6}{|c|}{ Coefficients $^{\mathrm{a}}$} \\
\hline \multirow[b]{2}{*}{ Model } & \multicolumn{2}{|c|}{$\begin{array}{c}\text { Unstandardized } \\
\text { Coefficients }\end{array}$} & $\begin{array}{l}\text { Standardized } \\
\text { Coefficients }\end{array}$ & \multirow[b]{2}{*}{$\mathrm{T}$} & \multirow[b]{2}{*}{ Siq. } \\
\hline & $\mathrm{B}$ & Std. Error & Beta & & \\
\hline $1 \quad$ (Constant) & 18,769 & 3,617 & & 5,189 & 0,000 \\
\hline Tata Letak & 0,503 & 0,089 & 0,594 & 5,622 & 0,000 \\
\hline
\end{tabular}

Sumber : Data pengolahan SPSS Dari jawaban koesioner 2020 
Regresi linier sederhana dilakukan untuk mengetahui hubungan fungsional atau kausal antara satu variabel dependent dan satu variabel independent. Bentuk persamaan regresi berupa :

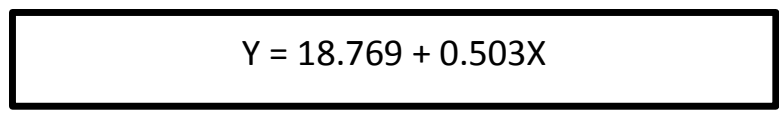

Dimana : Y (dependent) = FIFO;

$\mathrm{X}($ independent $)=$ tata letak

Berdasarkan perhitungan koefisien regresi didapat konstan sebesar 18,769 sedangkan koefisien B sebesar 0,503, yang berarti setiap ada kenaikan 1 variabel tata letak, maka akan ada kenaikan first in first out sebesar 0,503.

Berdasarkan Tabel 14., di atas menunjukan bahwa t hitung $=5,622$ dan sig. 0,000. Artinya bahwa nilai sig. $(0,000)<\alpha(0,05)$ dan $t$ hitung $(5,622)>t$ tabel $(2,00)$ maka Ho ditolak. Dengan demikian dapat disimpulkan bahwa tata letak secara parsial berpengaruh signifikan terhadap sistem first in first out. Artinya bahwa berjalannya first in first out dipengaruhi oleh faktor tata letak penyimpanan.

\section{Pembahasan}

\section{a. Variabel tata letak}

Tata letak penyimpanan memiliki 9 indikator, 210 - 285 dengan kriteria Cukup Baik, artinya sistem tata letak pemnyimpanan yang dilakukan PT Indofood CBP Sukses Makmur Tbk Divisi Packaging Purwakarta dinilai cukup baik berpengaruh terhadap sistem first in first out. Atau dapat dikatakan bahwa penataan tata letak bahan baku (Raw Material) dijalankan cukup baik perpengaruh terhadap berjalannya sistem first in first out di PT Indofood CBP Sukses Mkamur Tbk Divisi Packaging Purwakarta.

Berdasarkan pada data rekapitulasi distribusi frekuensi jawaban responden variabel tata letak, terdapat satu indikator yang memilki nilai skor rendah dan satu indikator yang memiliki nilai skor tinggi. Indikator rendah ada pada indikator "jenis bahan baku dikelompokan agar berada di satu titik untuk satu jenis" dengan nilai skor 221 dan indikator tertinggi ada pada indikator "susunan bahan baku sudah sesuai dengan standar" skor 251. dan seluruh indikator memiliki kriteria cukup

\section{b. Variabel first in first out}

Sistem first in first out memiliki 2 indikator, 210 - 285 dengan kriteria cukup baik, artinya sistem first in first out yang dilakukan PT Indofood CBP Sukses Makmur Tbk Divisi Packaging Purwakarta dinilai cukup baik dilaksanakan. Atau dapat dikatakan bahwa penataan tata letak bahan baku (Raw Material) dijalankan dengakn cukup baik sehingga dapat berjalannya sistem First In First Out pada bahan baku perusahaan.

Berdasarkan pada data rekapitulasi distribusi frekuensi jawaban responden variabel first in first out, terdapat satu indikator yang memilki nilai skor rendah dan satu indikator yang memiliki nilai skor tinggi. Indikator rendah ada pada indikator "Saya melakukan pengambilan barang yang mudah di jangkau" dengan nilai skor 220 dan indikator tertinggi ada pada indikator "Saya melakukan pencarian barang sesuai permintaan produksi" skor 258. dan seluruh indikator memiliki kriteria cukup.

\section{c. Pengaruh Parsial Tata Letak Terhadap sistem First In First Out}

Berdasarkan dasil penelitian menunjukan bahwa pengaruh Tata Letak terhadap sistem First In First Out sebesar 0,1537 atau 15,37\%. Dan berdasarkan uji hipotesis dengan tingkat signifikan $(\alpha)=5 \%$, degree of freedom $(\mathrm{df})=(\mathrm{n}-2)=60-2=58$ diperoleh $\mathrm{t}$ tabel $=2,00$. Berdasarkan Tabel 4.17 di atas, menunjukan bahwa t hitung $=2,00$ dan sig. 0,00. Artinya bahwa nilai sig. $(0,00)<\alpha(0,05)$ dan t hitung $(5,622)>$ t tabel $(2,00)$ maka Ho ditolak. Dengan 
demikian dapat disimpulkan bahwa tata letak secara parsial berpengaruh signifikan terhadap first in first out. Artinya bahwa berjalannya sistem first in first out dipengaruhi oleh faktor tata letak penyimpanan yang dilakukan oleh PT Indofood CBP Sukses Makmur Tbl Divisi Packaging Purwakarta.

Dengan demikian, semakin baik tata letak penyimpanan semakin baik juga sistem first in first out berjalan, khususnya pada PT Indofood CBP Sukses Makmur Tbk Divisi Packaging Purwakarta. Hal tersebut diperkuat pendapat Apple (1990), bahwa perencanaan fasilitas dan tata letak merupakan kegiatan menganalisis, bentuk konsep, merancang dan mewujudkan sistem bagi pembuatan barang atau jasa. Rancangan ini umumnya digambarkan sebagai rencana lantai, yaitu satu susunan fasilitas fisik (perlengkapan, tanah, bangunan, dan sarana) untuk mengoptimalkan hubungan antara petugas pelaksana, aliran barang, aliran informasi, dan tata cara yang diperlukan untuk mencapai tujuan usaha secara efisien, ekonomis, dan aman.

\section{d. Pengaruh Simultan antara Variabel $X$ terhadap $Y$}

Berdasarkan dari hasil perhitungan dalam penelitian ini, diperoleh nilai pengaruh simultan sebesar 0,1188 atau $11,88 \%$. Artinya bahwa berjalannya sistem first in first out di pengaruhi oleh variabel tata letak sebesar $11,88 \%$. Sedangkan sisanya dipengaruhi oleh variabel lain sebesar $88,12 \%(=1-0,1188)$ yang tidak diteliti $(\varepsilon)$.

Semakin baik tata letak penyimpanan semakin baik juga sistem first in first out berjalan, khususnya pada PT Indofood CBP Sukses Makmur Tbk Devisi Packaging Purwakarta. Ini dapat dilihat dari hasil Berdasarkan uji koefisien determinasi diperoleh nilai R (R2) sebesar 0,594 . Artinya adalah bahwa sumbangan pengaruh variabel independen terhadap variabel dependen (first in first out) adalah sebesar 59,4\%, sedangkan sisanya 40,6\% dipengaruhi oleh variabel lain yang tidak ikut dibahas dalam penelitian ini. Hal tersebut diperkuat menurut pendapat Tompkins, dkk., (2010), dalam penyimpanan barang di gudang agar nantinya barang yang disimpan tersebut tidak mengalami kerusakan sangatlah dibutuhkan suatu metode, cara maupun prosedut tertentu. Setidaknya dalam penyimpanan barang di gudang kita mengenal adanya dua sistem yaitu LIFO (last in first out) dan FIFO (first in first out). LIFO adalah suatu sistem atau cara penyimpanan barang dalam gudang yaitu barang yang datang terakhir digunakan terlebih dahulu.

\section{SIMPULAN DAN SARAN}

Berdasarkan hasil penelitian dan pembahasannya dari hasil jajak pendapat karyawan Divisi Packaging di PT Indofood CBP Sukses Makmur TBK Purwakarta, dapat ditarik simpulan bahwa Tata Letak penyimpanan bahan baku PT Indofood CBP Sukses Makmur Tbk Divisi Packaging Purwakarta terbukti berpengaruh positif dan signifikan terhadap first in first out (FIFO). Besarnya persentase pengaruh Tata Letak penyimpanan bahan baku terhadap first in first out sebesar 35,3\%. Hal ini berarti semakin baik Tata Letak penyimpanan yang dimiliki, maka semakin baik pula berjalannya first in first out (FIFO) di PT Indofood CBP Sukses Makmur Tbk Divisi Packaging Purwakarta sebesar 35,3\%.

Sedangkan berdasarkan hasil temuan dalam penelitian ini, saran yang dapat dikemukakan adalah bagi peneliti selanjutnya untuk dapat mengembangkan penelitian ini dengan melakukan penelitian pada variabel-variabel lain yang belum diteliti pada penelitian ini yang dapat mempengaruhi FIFO.

\section{DAFTAR PUSTAKA}

Apple, J., M. (1990). Tata Letak Pabrik dan Pemindahan Bahan. 3rd Edition, Bandung : ITB Bandung

Badudu \& Zain. (2001). Kamus Umum Bahasa Indonesia. Jakarta : Pustaka Sinar Harapan.

Hugiono \& Poerwantana (2000). Pengantar Ilmu Sejarah, Jakarta : PT Bina Aksara

Larici, Y. P., \& Abdul, F. W. (2019). Ketepatan Pengaruh Manajemen Logistik Terhadap Tingkat 
Kepuasan Pelanggan PT . Bhinneka Bajanas Cabang Cikarang, Jurnal Logistik Indonesia, 3(2), 101-110.

Nasiruddin \& Syaifulloh, M. (2019). Analisis Model Pencatatan Persediaan Sistem Periodik dengan Metode First-In First-Out ( Fifo ) di Badan Usaha Milik Pesantren Kabupaten, Jurnal Pro Bisnis, 12(1), 29-42.

Noerfajr, L., \& Suliantoro, I. H. (2016). Usulan Perancangan Tata Letak Gudang dengan menerapkan Sistem Management Warehouse di PT. Sandang Asia Maju Abadi, Industrial Engineering Online Journal, 5(4).

Reid, R. D., \& Sanders, N., R. (2013). Operations Management, 5th Edition, Hokoben : John Wiley and Sons.

Russell, R. S., \& Taylor, B., W. (2016). Operations and Supply Chain Management, 9th Edition, Hokoben : John Wiley and Son.

Tompkins, J. A., White, J. A., Bozer, Y.A., \& Tanchoco, J., .M., .A. (2010). Facilities Planning, Fourth Edition. New York :John, Wiley

Sugiono. (2016). Metode Penelitian Kuantitatif, Kualitatif, dan R\&D, Edisi 2, Bandung : Alfabeta 